\title{
EL NACIMIENTO DE UN GÉNERO: JOSÉ EMILIO PACHECO EN EL EXCÉLSIOR
}

\author{
A NEW GENRE IS BORN: JOSÉ EMILIO PACHECO \\ IN THE DAILY NEWSPAPER EXCÉLSIOR
}

\author{
Rafael Olea Franco \\ El Colegio de México \\ rolea@colmex.mx \\ orcid: 0000-0003-1759-6886
}

Resumen: Este trabajo examina algunos de los textos publicados por el escritor mexicano José Emilio Pacheco (1939-2014) en el diario Excélsior, a partir del 5 de agosto de 1973, en una columna semanal titulada "inventario". Se trata de escritos heterogéneos, donde se mezclan la crónica (literaria e histórica), la ficción e incluso la poesía. Aunque con interrupciones, esta columna se publicó hasta el 4 de julio de 1976; se reanudó a fines de ese mismo año, en la recién inaugurada revista Proceso, en la cual se consolidó y se convirtió en una marca identitaria del autor. Aquí se sostiene que los rasgos generales de todo el conjunto de los "inventarios" de Pacheco son visibles ya en esa primera etapa de Excélsior.

Palabras clave: José Emilio Pacheco (1939-2014); literatura mexicana

del siglo xx; la crónica en México; la crítica literaria en México;

diario Excélsior.

Abstract: This article examines some of the contributions made by Mexican writer José Emilio Pacheco (1939-2014) to the newspaper Excélsior, in a weekly column entitled "Inventario" which began on August $5^{\text {th }}, 1973$. The texts published there are of a heterogeneous nature, mixing both historical and literary chronicle, fiction, and even poetry. Though occasionally interrupted, the column continued through to July $4^{\text {th }}, 1976$, reappearing later that year in the newly launched magazine Proceso, in which it became established as one of the author's hallmarks. In this essay the point is made that the defining traits of Pacheco's "inventories" as a whole are already discernible in this early stage in the Excélsior.

Keywords: José Emilio Pacheco (1939-2014); 20th century Mexican literature; chronicle in Mexico; literary criticism in Mexico; Excélsior newspaper.

Recepción: 7 de noviembre de 2019; aceptación: 5 de mayo de 2020. 
El 26 de julio de 1903, en su columna regular "La semana alegre”, del periódico El Imparcial, Ángel de Campo (alias Micrós) publicó un artículo sobre uno de sus antecesores, Enrique Chávarri, quien desde 1871, bajo el seudónimo de Juvenal, difundió en El Monitor Republicano sus charlas dominicales, las cuales duraron la friolera de treinta y dos años. En su reflexión retrospectiva de la labor de Chávarri, Micrós se quejaba de un cambio operado a fines del siglo xIx, cuando las exigencias de una prensa cada vez más regular y periódica forzaron a la crónica, género visible en México desde décadas atrás, a una constancia absoluta; por ello, Micrós, también cronista dominguero, se quejaba del tormento que inflige a un escritor el deber de encontrar un tema semanal:

Y no hay suplicio comparable al de buscar la nota cómica una vez por semana; durante treinta y dos años; no hay labor más cruenta que la de exprimir el cerebro en las redacciones; entre un matado, un problema monetario; una rectificación; un cablegrama y un soneto, para obtener con más esfuerzo que una lágrima, el asunto amarguísimo que trata de regocijar a los demás; son dignos de la palma quienes, en el silencio del gabinete, a solas con su poca vena, o su mal humor, o sus enfermedades; deponen el ceño, y coléricos quizá... se enfrentan con el público y le dicen la frase chispeante y lo saludan con la sonrisa periodística (De Campo 1991 [1903], pp. 205-206) ${ }^{1}$.

Si eso afirmaba De Campo respecto de los treinta y dos años de las crónicas de Juvenal, ¿qué podría decirse de las cuatro décadas de José Emilio Pacheco en la escritura cotidiana de los textos que desde sus orígenes aparecieron bajo el simple encabezado de "inventario"? Claro que él no se sintió obligado a desplegar de manera permanente ese tono jocoso, pero a la vez serio, de sus predecesores Juvenal y Micrós, con quienes, estoy seguro, no le hubiera disgustado que se le comparara.

Como he tenido oportunidad de mencionar en otro contexto, gracias a la generosidad de Cristina y José Emilio Pacheco, el

1 Uno de los primeros en tener la sensación de que, pese a su estado de ánimo, un periodista dominical debía asumir un tono humorístico, fue MANUEl GutiérRez NÁJERA (1859-1895), cuya prolífica vida literaria estuvo tan ligada al periodismo. Él remató así un artículo de la década de 1880: "Olvidaba que a los escritores de literatura dominguera nos sucede lo que a los clowns: se presentan a veces en el circo con el alma rebosando amargura, y sin embargo, tienen que hacer reír al público" (1912, p. 165). 
14 de enero de 2014, doce días antes de la muerte del escritor, la estudiosa francesa Anne Cécile García -quien estaba redactando su tesis doctoral sobre Pacheco (cf. García 2016) - y yo pudimos pasar unas maravillosas horas con ellos. En medio de la erudita digresión con que José Emilio solía regalar a quien tuviera la dicha de escucharlo, mencionó un dato esencial para comprender los orígenes de un género que él creó para deleitar y enseñar durante décadas a sus fervientes lectores. Nos comentó que, a iniciativa de Fernando Benítez, tradujo para México en la Cultura, el suplemento cultural del diario Novedades que éste dirigió entre 1949 y 1961, algunas notas aparecidas en revistas francesas asequibles en la época, con lo cual se buscaba contrarrestar la influencia cultural de Estados Unidos. Las notas, de muy diversa índole, se publicaron sin problemas por un tiempo, hasta que France Press, la dueña de los derechos, demandó el pago de las regalías correspondientes, las cuales, contaba riendo José Emilio, rebasaban el presupuesto completo de la publicación. Por suerte así lo entendieron los franceses, por lo que México en la Cultura continuó difundiéndose, ya sin ningún acoso económico externo, más allá de las precarias condiciones financieras de este tipo de suplementos y revistas, que en nuestro país siempre logran sobrevivir con enorme esfuerzo. Conviene aclarar que las notas traducidas anónimamente por Pacheco indicaban tanto el nombre del autor del texto original como el copyright de la agencia France Press; esto prueba que, si bien no había dinero para pagar derechos, tampoco existía la intención de apropiarse impunemente del trabajo ajeno, sin reconocimiento alguno. Me pregunto incluso si el propio Pacheco recibió un mínimo pago por su labor de traducción. Comoquiera que haya sido, su paso por México en la Cultura, donde entre 1959 y 1961 publicó variados textos -desde reseñas de libros y algunos de sus primeros cuentos, hasta artículos anónimos cuya autoría sería imposible rastrear con precisión-, fue una etapa decisiva para su formación como escritor, según reconoció en numerosas ocasiones en que agradeció públicamente a Benítez. Considero que el amplio interés cultural desplegado en México en la Cultura por el entonces muy joven Pacheco es un claro antecedente de la finalidad esencial de sus inventarios.

Ahora bien, en sentido estricto, el nacimiento del género "Inventario" (si se puede considerar un género, porque sólo tendría un único pero egregio practicante) se produjo en el diario Excélsior, cuyo Diorama de la Cultura recibió su primera 
colaboración el domingo 5 de agosto de 1973, sin firma, pero ya bajo el nombre de "Inventario"2. Con una regularidad no exenta de períodos de silencio, esta columna semanal duró hasta el 4 de julio de 1976, cuatro días antes de que el malhadado golpe del gobierno de Luis Echeverría enterrara uno de los proyectos editoriales más interesantes del siglo xx en México. Una de las consecuencias inmediatas de este suceso fue la salida de Julio Scherer como director de Excélsior, acompañado de muchos de los colaboradores del diario, quienes, por el bien del periodismo independiente, a los pocos meses lanzaron el semanario Proceso, donde los inventarios se consolidaron y se convirtieron en costumbre de sus lectores, de hecho hasta el 25 de enero de 2014, un día antes de la desaparición física del autor³

En general, los hiatos de silencio de Pacheco en el Diorama duraron apenas un par de semanas. Pero también hubo un período de varios meses: entre noviembre de 1974 y mayo de 1975 no se publicó su columna, debido a que él cumplió con otros compromisos; porque, cabe recordar, además de escritor,

${ }^{2}$ Como describiré más abajo, Pacheco nunca creyó en la supuesta originalidad. Es probable que el término "inventario" haya circulado en la cultura de la época, aunque, hasta donde he logrado dilucidar, Pacheco fue el primero en usarlo de manera regular. En la misma época, Juan José Arreola, uno de sus maestros, y a quien ayudó a transcribir los textos orales de su libro Bestiario, bautizó un libro suyo con el título de Inventario (1976). Se trata de la compilación parcial de las columnas cotidianas de Arreola en el diario El Sol de México, difundidas bajo el encabezado "De sol a sol", del 8 de febrero de 1975 al 10 de diciembre de 1976. En la cuarta de forros del libro, apareció, de puño y letra de Arreola, una bella descripción sobre el término: "Inventario, del latín inventarium, es la relación ordenada de los bienes y demás cosas pertenecientes a una persona o entidad. Pero también el documento en que constan esas cosas. Antonio de Nebrija dice que «inventario es la lista de lo hallado". He aquí pues que yo me pongo a inventariar desde ahora los objetos de mi alma y los hallazgos propios y ajenos en su natural confusión. Abriendo de vez en cuando, creo, la Puerta de Marfil".

${ }^{3}$ Pacheco 2017 ofrece una valiosa compilación que contiene alrededor de un tercio de los textos de ambas etapas. Debe agradecerse este hito editorial y a quienes seleccionaron el material (Héctor Manjarrez, Eduardo Antonio Parra, José Ramón Ruisánchez y Paloma Villegas, dirigidos anónimamente por Marcelo Uribe, amigo y editor de Pacheco); sólo cabe lamentar que esta edición carezca de un instrumento que se antoja relativamente factible en esta era digital: índices onomásticos que guíen al lector en la consulta de los diversos contenidos de la antología. Como los inventarios que cito no forman parte de ella, los identificaré tan sólo por su fecha -según describo más abajo, casi siempre aparecieron en la misma página del suplemento cultural de Excélsior. 
fue académico (quizá su ejercicio de la docencia universitaria fomentó su costumbre de leer la crítica sobre su obra, deferencia a la que no siempre condescienden los autores, aunque a todos les interesa que se estudie su obra). Durante su ausencia, el espacio de los inventarios fue ocupado por la columna "Baulmundo"; cuando él reanudó su labor, el $1^{\circ}$ de junio de 1975, antecedió el texto con esta apostilla: "El redactor de esta página quiere expresar públicamente su agradecimiento a quienes durante su ausencia escribieron la sección «Baulmundo»". La nota buscaba diluir una confusión, pues no faltó quien creyera que se trataba del mismo autor ${ }^{4}$. Por cierto que en el primer número de la revista Proceso, que empezó a circular el 6 de noviembre de 1976, el emigrado "inventario" apareció de forma anónima; sólo por excepción (por ejemplo, el 20 de noviembre de 1976), la columna se distinguió bajo el nombre completo de José Emilio Pacheco, a veces con sus iniciales o bien con la leyenda "Por la transcripción JEP". Después, sus numerosos seguidores no necesitaron ninguna identificación autoral para reconocer su singular escritura, anunciada bajo el simple título de la columna.

Los inventarios del Diorama sumaron 153 entregas, de dimensiones más bien fijas, gracias a un tipógrafo diligente, quien mediante diversos elementos gráficos (fotografías, dibujos, incluso anuncios de venta de libros) ajustaba el texto a las cinco columnas de una página completa, casi siempre la última del suplemento, impreso en dieciséis páginas de tamaño tabloide. Para acatar las restricciones del editor en cuanto a la

${ }^{4}$ Este equívoco lo siguió hasta la revista Proceso, donde al final de su columna del 14 de noviembre de 1977, añadió: "El autor de estas notas agradece a Marco Antonio Campos la generosidad de sus apreciaciones en el último número de Proceso. Debe hacer sin embargo una aclaración: él ha sido en efecto el casi invariablemente anónimo redactor de columnas informativas como «Simpatías y diferencias» (1960-63), «Calendario» (6370), «El minutero» (69) e «Inventario» (a partir de 1973), entre otras. Pero «Baulmundo» (octubre de 74-mayo de 75) no es trabajo suyo sino de Gustavo Sainz, primero, y posteriormente José de la Colina y Danubio Torres Fierro" (p. 57). Una semana antes, Campos había afirmado, en un artículo donde alababa la labor de Pacheco como difusor de uno de los volúmenes de Mi diario, de Federico Gamboa, que él era también el autor de columnas como "Minutero", "Baulmundo" e "Inventario". Este desliz es peccata minuta; más todavía si se considera que la primera y generosa frase de Campos fue un ditirambo: "José Emilio Pacheco, a pesar de no llegar a los 40 años de su edad, es quizá el mejor hombre de letras de nuestro país” (1977, p. 60). 
extensión de sus textos, Pacheco se guiaba por el número de cuartillas escritas a máquina (ahora hasta se exige una cantidad máxima de caracteres). Según informa Humberto Musacchio en su libro sobre el periodismo cultural en México, el Diorama de la Cultura nació en 1949, cuando este suplemente empezó a incluirse como parte del periódico Excélsior, con una numeración continua respecto de éste; en 1969, el suplemento adquirió autonomía (con foliación independiente y, por lo regular, 16 páginas). Una semana después de inauguradas las colaboraciones de Pacheco, Ignacio Solares asumió la labor de coordinador del Diorama, donde también estaban presentes muchos otros intelectuales, jóvenes y ya consagrados, como: Raquel Tibol, Alberto Dallal, José Antonio Alcaraz, Froylán M. López Narváez, Jorge Ayala Blanco, Maruxa Vilalta, Olga Harmony, Héctor Azar, Esther Seligson, Jorge Hernández Campos, Luis Cardoza y Aragón, etcétera (véase Musacchio 2007).

Quien se atreviera a intentar dibujar una breve y somera descripción de la naturaleza de esos textos de Pacheco estaría condenado de antemano al fracaso, tal como sucede con el narrador del famoso relato "El Aleph", ese Borges ficticio que después de haber visto el universo completo por medio del Aleph, una minúscula esfera tornasolada, de apenas unos cuantos centímetros, se plantea: "Arribo, ahora, al inefable centro de mi relato; empieza, aquí, mi desesperación de escritor. Todo lenguaje es un alfabeto de símbolos cuyo ejercicio presupone un pasado que los interlocutores comparten; ¿cómo transmitir a los otros el infinito Aleph, que mi temerosa memoria apenas abarca?" (1996 [1945], t. 1, p. 624). Y luego de enlistar varios ejemplos donde los místicos acuden a emblemas en su intento por representar pálidamente la divinidad, concluye: "Por lo demás, el problema central es irresoluble: la enumeración, siquiera parcial, de un conjunto infinito... Lo que vieron mis ojos fue simultáneo; lo que transcribiré, sucesivo, porque el lenguaje lo es. Algo, sin embargo, recogeré” (p. 625).

Aunque no me postulo como escritor, sino como un simple y modesto lector, el trance en que me encuentro es análogo: ¿Cómo transmitir ese universo que son los inventarios de Pacheco? Para ello, recurriré al mismo procedimiento en el que, en última instancia, se escuda el narrador de "El Aleph" al enunciar esa larga frase que constituye la parte central del relato, donde ofrece una lista inconexa de algunas de las imágenes vistas; ese método es la enumeración dispar, que a veces ha sido denomina- 
da, de forma imprecisa, como "enumeración caótica"; a mi juicio, no hay ningún caos en la larga lista de imágenes que son percibidas por el narrador de "El Aleph", porque mediante ella muestra la asombrosa pluralidad del universo, no su aparente desorden.

El inventario inaugural exhibe ya algunos rasgos que marcarán la serie durante cuatro décadas, primero en Diorama y luego en Proceso. Para empezar, la diversidad de elementos culturales que atraían a Pacheco, visible desde su construcción fragmentaria, porque en general solía tratar muchos temas, lo cual derivaba en varios subtítulos, como el inicial, "las mariposas son libros", donde habla de lo que hoy se llamaría "subliteratura": "En pocos días la industria literaria ha sufrido la muerte de Henri Charriere y la autojubilación de Corín Tellado" (5 de agosto de 1973, p. 16). Cabe notar que él se refiere a la "industria literaria", no a la literatura en sí. Charriere firmó la exitosa novela Papillon, de 1969, llevada con éxito al cine en 1973, con Steve McQueen como protagonista. Por su parte, al anunciar su jubilación literaria, Corín Tellado declaró con "castiza brusquedad", aunque con tono femenino: "Llevo veinticinco años pariendo una novela cada cuatro días... y he decidido colgar los trastos”. La revisión de los hábitos literarios de ambos autores revelaba datos desconcertantes.

Charriere, múltiple fugitivo de las cárceles de la Guyana francesa, parecía ilustrar por antonomasia la antigua idea de que sólo se debe tomar la pluma cuando se han vivido experiencias trascendentes. Pero sus detractores, envidiosos por el millón de ejemplares que él había vendido, probaron "que Papillon era más bien un trabajo de ficción industrial que el relato en vivo y en directo de una experiencia irrepetible; que las dotes narrativas correspondían no tanto al antiguo hampón... como a los varios escritores anónimos que, por órdenes de una casa editora con buen ojo mercantil, rehicieron y aderezaron el manuscrito elemental de Charriere"; la novela, pues, se debía, en términos actuales, a un grupo de "ghost writers". En cambio, doña Corín Tellado, como la llama Pacheco, sí era la pródiga autora del cúmulo de novelas propagadas bajo su firma, porque, al contrario de lo que todo mundo creía, no se trataba "de un sindicato de escribientes amparados bajo un seudónimo común, un nombre genérico, una marca industrial sino de una persona capaz de sobrepasar (en cantidad) la obra de varias generaciones literarias". La frase "(en cantidad)", escrita como una aclaración entre paréntesis, imprime un sutil matiz irónico 
a su afirmación, porque implica que Tellado sólo es superior en cantidad, no en calidad estética. Como devastador remate, Pacheco describe los temas de esta autora, cuya labor reconoce primero por sus enormes aportaciones al fisco español:

Corín Tellado dio a España casi tantas divisas como la Costa Brava o la Semana Santa en Sevilla. Emperatriz de la novela rosa, genial manipuladora de nuestra entrañable cursilería, "pornógrafa inocente", en mil historias que son la misma historia -de Ella y su jefe a Me casé con él, desde Se busca esposa hasta Lo encontré asi- Corín Tellado entregó a su público lo que buscaba, lo que se dejaba imponer: evasión, enajenación, entretenimiento, esperanza, conformismo: drogas en letra impresa, pócimas verbales para anestesiar el sentimiento de la injusticia social, la soledad, la decepción, el abandono, el horror cotidiano de nuestras sociedades hechas para aplastar a todas sus mujeres.

En la frase inicial, él se muestra como avezado ejecutor del "arte de injuriar" (Borges dixit), pues sugiere que, como escritora, Collado era más bien una inapreciable contribuyente fiscal. Pero no todo es diatriba, porque el final de esta cita muestra que Pacheco no asume una actitud moralizante, en busca de suprimir una práctica aparentemente deleznable, sino que comprende parte de la función social de ese tipo de literatura (nos guste o no $)^{5}$. En cuanto al ingreso de Pacheco a la cultura letrada, él mismo comentó, en su temprano texto autobiográfico, basado en la conferencia que pronunció en la Casa del Lago el 11 de noviembre de 1965: "Pasé la mitad de mi infancia con mis abuelos en Veracruz. Ellos me enseñaron a leer. Obsequio

${ }^{5}$ Mi colega de El Colegio de México, Soledad Loaeza, a quien agradezco la lectura de una versión previa de este trabajo, declara que en su adolescencia fue ferviente lectora de Corín Tellado, y me señala un aspecto de esta función social no incluido por Pacheco: la contribución de esas novelas a lo que se podría denominar como la educación sentimental de sus jóvenes lectoras. Por cierto, ella confiesa que a los catorce años escribió una novela nutrida por las fórmulas de Collado, la cual fue censurada y desaparecida por las monjas del colegio donde estudiaba, quienes, no conformes con ello, incluso la expulsaron. Creo que no cometo una infidencia si transcribo sus palabras, plenas de buen humor: "Fui experta en las novelas de Corín Tellado. Me sabía de memoria las fórmulas que utilizaba para describir a sus personajes: «las sienes plateadas», «los senos turgentes», etc., etc. A los 14 años escribí una novela apócrifa que llegó a manos de las monjas del colegio. Me la quitaron y me expulsaron por escribir "pornografía». Ahí se terminó mi carrera literaria”. 
a mi aplicación fue un resumen infantil de Quo Vadis?, el primer libro que leí" (1966, t. 1, p. 244). Así pues, él recuerda haber entrado al mundo de la lectura por medio de la versión abreviada de una novela del polaco Sienkiewicz, no de una pretendida obra "original"; quizá por ello nunca guardó devoción absoluta al fetiche de la originalidad, como se observa desde 1958 en sus dos cuentos de la plaquette La sangre de Medusa, escritos bajo el notorio influjo de Borges. Asimismo, en Las batallas en el desierto (1981), él despliega su familiaridad con la cultura de masas, ésa que alimentó su infancia con programas de radio y cómics, si bien no con la llamada novela sentimental, romántica o rosa al estilo de Corín Tellado.

Respecto de los motivos para que Tellado hubiera abdicado a la corona del escritor más prolífico, Pacheco lanza diferentes hipótesis: 1) derrota del sentimentalismo peninsular a manos de la "melcocha autóctona" de Yolanda Vargas Dulché; 2) triunfo de la televisión sobre un medio escrito que, a pesar de todo, requiere un mínimo esfuerzo de lectura; 3) crecimiento de la conciencia en un vasto núcleo femenino, hastiado del engañoso cuento de hadas sobre la mujer de condición social inferior a quien el amor convierte en millonaria; del chofer/ mandadero/ labrador que se casa con la hija del patrón y hereda industrias, flotas mercantes, latifundios; 4) descrédito de los finales felices, porque, en un mundo tan horrible como el nuestro, ya nadie cree en ellos. Me parece que las dos primeras hipótesis son las más plausibles, como se aprecia en dos rasgos de la cultura de masas. Primero, en la permanencia de las novelas semanales impresas, en esa misma década de 1970 y por varias más (incluso las novelas de Tellado han revivido, ahora en versión digital). Segundo, en la profusión de esos bodrios denominados telenovelas, en cuya manufactura compiten las dos grandes televisoras mexicanas por ver cuál aporta más al proceso de la educación pública, ya que el Estado lo hace tan mal, como estos mismos medios recalcan todo el tiempo. Aunque quizá la envidia (el pecado más universal de todos) genere mis juicios, porque, según informa la Enciclopedia Británica de los pobres, es decir, la Wikipedia, a la muerte de María del Socorro Tellado López (1927-2009), su nombre oficial, se habían vendido (y traducido a 27 idiomas) más de 400 millones de ejemplares de los miles de novelas que escribió; y aquí debo suspender mi escepticismo congénito, ya que, por lo general, rechazo que de manera automática se asocie el número de libros vendidos con el de 
libros leídos. La Unesco misma se rindió ante tan abrumador éxito: en 1962, la declaró como el escritor de lengua española más leído de la historia, sólo detrás de Cervantes. Pero como la Wikipedia no dice que Corín haya "colgado los trastos" en 1973, sospecho que su retiro fue una mera treta publicitaria (¿゚ acaso su infinito público reclamó su regreso, como un siglo antes los lectores franceses exigieron a Ponson du Terrail que reviviera a su héroe popular Rocambole?).

Un último detalle sobre ese inventario: la sección dedicada a Corín Tellado se titula "Boquitas selladas", una clara alusión a la novela Boquitas pintadas (1969), de Manuel Puig, que este escritor argentino anunció, en actitud desafiante, como un folletín en dieciséis entregas, o sea, como una obra que seguía el modelo de esa cultura de masas a la que pertenece Corín Tellado.

Bajo el título "Letras minúsculas", columna del 27 de enero de 1974 compuesta por breves fragmentos, Pacheco escribe: "Quizá la mejor injuria de la literatura hispanoamericana es la frase de Manuel Ugarte sobre Vargas Vila: «Supo poner vanidad en el talento, pero no logró poner talento en la vanidad»" (p. 16). Según Borges, la mayor injuria literaria en nuestra lengua era la que asestó precisamente el vilipendiado escritor colombiano Vargas Vila contra el peruano José Santos Chocano, luego de que, en 1920, éste sobreviviera a la pena de muerte que le había granjeado en Guatemala su irrestricto apoyo al dictador Manuel Estrada Cabrera, defenestrado ese año; gracias a la intervención de numerosos políticos e intelectuales, sobre todo hispanoamericanos, le fue conmutada la sentencia mortal. A este fallido destino trágico se refiere su detractor Vargas Vila en las palabras recordadas con morosa delectación por Borges (1996 [1936], t. 1, p. 422): "Los dioses no consintieron que Santos Chocano deshonrara el patíbulo, muriendo en él. Ahí está vivo, después de haber fatigado la infamia”. La alusión a Vargas Vila no es gratuita, porque él representa, en Hispanoamérica, un punto máximo de eso que también ejerció con enjundia Corín Tellado: la cursilería; como muestra, menciono los gloriosos títulos de algunas de sus novelas: Aura o Las violetas, Flor de fango, y la inefable trilogía Lirio blanco, Lirio rojo y Lirio negro. Más benévolo y comprensivo ante ese rasgo humano (no sólo un simple defecto individual), Pacheco propone en su inventario: "Quizá la cursilería sea en el fondo una forma de tristeza y de amor a la muerte" (p. 16), enigmática frase cuyo sentido pleno no logro desentrañar. 
Con este antecedente, no resulta extraño que él haya dedicado una sección completa de su inventario del 17 de agosto de 1975 a elaborar una "Pequeña guía de la cursilería". Su reflexión empieza con la referencia filológica al diccionario de Joan Corominas, para quien la palabra cursi apareció en Andalucía hacia 1865 y debió tomarse del árabe marroquí, donde kúrsi significa "figurón, personaje importante" y, metafóricamente, "presuntuoso". Luego describe que Anderson Imbert define lo cursi como "la expresión, atildada pero a destiempo, de lo elegante" (p. 16); además de fabular que, en la segunda mitad del siglo XIX, vivió en Madrid o en Sevilla una familia de apellido Sicur, cuyas mujeres presumían de elegantes en su habla, modales y vestidos, aunque las otras personas se reían de ellas y, para disimular la burla, idearon esta estratagema: en vez de llamarlas Sicur, invirtieron las sílabas de su apellido para referirse a ellas como las Cursi; como se ve, Anderson Imbert carecía de documentos que probaran su hipótesis, pero no de imaginación. Menciona también Pacheco, entre otras posibilidades, la conjetura de Enrique Tierno Galván, quien aduce que se trata de la apócope de la letra "cursiva" inglesa, que entró en España en el primer tercio del siglo xix y se diferenció de la caligrafía tradicional española como atildamiento burgués, así como la de José Martí, para quien cursi era la transcripción fonética de la palabra inglesa courtesy (la cual ciertamente para el oído hispánico tiende a sonar más o menos como kértsi, "exagerado saludo femenino"). Casi al final de su breve pero fundamentada disquisición, afirma Pacheco que "El estudio de «lo que, con apariencia de elegancia o riqueza es ridículo y del mal gusto", ofrece aun posibilidades ilimitadas" ( $i d$.$) .$

Por mi parte, agrego que lo cursi es también lo fallidamente romántico, aunque a veces las fronteras entre estos dos puntos son porosas: los poemas románticos del primer Pablo Neruda de Veinte poemas de amor y una canción desesperada (1924) se abisman en la pura cursilería cuando se les imita o parafrasea. La conclusión de Pacheco sobre lo cursi es aguda y contundente: "Quedan por hacerse una interpretación de lo cursi en términos de clases sociales y otra indagación psicoanalítica, ya que invariablemente los cursis (como los corruptos y los imbéciles) son los otros y uno siempre es ciego a su propia cursilería" $(i d$.$) . Así, de forma repentina, el autor abandona la inquisición$ filológica y nos asesta un dardo de la más pura invectiva satírica; sátira en el sentido más hondo del término, o sea, no como 
crítica de las costumbres de un grupo social específico, identificable geográfica e históricamente, sino como punzón hiriente sobre la naturaleza humana misma; porque todos estamos íntimamente convencidos de que los cursis, corruptos e imbéciles son los demás, ya que por supuesto nosotros somos un irrefutable dechado de buen gusto, honradez e inteligencia.

El inventario del 28 de octubre de 1973, titulado "La montaña mágica”, empieza con esta visión apocalíptica:

Estamos en vísperas de la tercera guerra mundial. El engranaje de las pasiones y de los intereses, de la provocación y la respuesta, nos ha llevado al borde del abismo. Para detener esta catástrofe, que inexorablemente será la última, doce sabios que han recibido el Premio Nobel o lo obtendrán si hay todavía un futuro, se reúnen en una aldea de los Alpes. Un millonario que conquistó su fortuna mediante la venta indiscriminada de armas y la explotación de prostíbulos, levantó allí una kongresshaus de vidrio y concreto que aloja el simposio sobre el tema "Approaches to Survival" (p. 16).

De entrada, este texto parece referirse a la entonces candente "guerra fría" (como se la llamó) entre Estados Unidos y la Unión Soviética; sin embargo, en el siguiente párrafo se percibe que se trata de la descripción de una novela de Arthur Koestler, escritor de origen húngaro, naturalizado británico, quien, juguetonamente, bautizó su obra como The call girls, nombre que se dan a sí mismos esos científicos para aludir a su permanente disponibilidad telefónica. Después, Pacheco describe algunas características de la novela de Koestler, publicada ese mismo año. Este inventario exhibe la tradición cultural en la que él se inscribe, la cual disiente del consejo decimonónico de que el lector debía manejar los textos en su lengua fuente, en particular el francés o el inglés; desde esa perspectiva, él sirve como eficiente mediador cultural para quienes sólo conocen su propio idioma nativo, en este caso, el español.

$\mathrm{Al}$ desplegar sus habilidades como escritor (y como conversador), Pacheco exhibía dos características complementarias: la erudición y el estilo digresivo. Al contrario de lo que parece, la segunda de éstas no fue una falla sino una virtud, pues le conquistó una gran variedad de receptores, quienes sabían que cualquiera de sus inventarios podría contener datos de diversa índole, provenientes de más de una tradición cultural y de más de una disciplina (no sólo de la literatura y la historia). El ejem- 
plo que comento es una muestra de ello, porque luego de describir la novela de Koestler, se menciona la más reciente obra de Milan Kundera, o bien se reflexiona sobre Malcolm Lowry, o sobre la previa Feria del Libro de Frankfurt, la más grande del mundo, cuyos asistentes se habían desconcertado por la difusión de inéditos de Goebbels, Goering o Bormann, fenómeno sobre el cual él concluye, con sutil ironía: "Se dice que no es tanto señal de un renacimiento nazi como prueba de que Hitler y sus secuaces salen del Walhala del mito para volverse una mercancía como cualquier otra" $(i d$.$) . Y con este sencillo$ ejemplo llegamos a una de las modalidades permanentes de su escritura, que también ha asomado en citas previas: el manejo de la ironía. Una ironía que incluso alcanza el humor negro, como lo llamamos por facilidad descriptiva. En el fragmento "Farenheit 451", que cierra ese inventario del 28 de octubre de 1973, se lee: "Salvador Barroso nos informa que también Juan Carlos Onetti ha tenido el honor de que un libro suyo alimente las hogueras de Santiago [de Chile]. Y pide que se aclare a quien corresponda que Juntacadáveres (1965) es una novela: no, como creyeron, una biografía de Pinochet" $(i d$.$) . El 11$ de septiembre de 1973 se había desatado el sangriento golpe de Estado de Pinochet contra el gobierno democrático de Salvador Allende, que culminó con la muerte de éste y con una inmediata ola masiva de disidentes asesinados, de lo cual para octubre ya se tenían abundantes noticias en México. Pacheco ironizó sobre este tema después de haber dedicado su texto completo del 15 de septiembre, titulado "de Lautaro a Salvador Allende: un mínimo repaso", a revisar las condiciones históricas que cuatro días antes habían provocado la caída de Allende; así pues, la ironía no fue su elección inmediata frente a tan terrible suceso histórico (actitud que ahora incluso se consideraría como políticamente incorrecta). Conviene recordar que para percibir este tipo de corrosiva ironía, y tal vez gustar de ella, se requiere que el lector coincida con el autor en lo que Linda Hutcheon (1992) denomina "competencia ideológica", es decir, en los límites permisibles para burlarse gozosamente de algo o alguien (p. ej., un ferviente cristiano juzgará como una injuria el mejor chiste sobre Cristo contado por un jubiloso ateo).

También es pertinente analizar los encabezados del primer y el último fragmento de este inventario: "La montaña mágica" y "Farenheit 451". Algunos subtítulos de los inventarios no desempeñan la única función de anunciar un tema distinto, 
relativamente afín a los fragmentos previos, sino que operan como una especie de epígrafe para cada apartado. En la referida y extensa novela La montaña mágica, publicada por Thomas Mann en 1924, el joven Hans Castorp llega al sanatorio, ubicado en una montaña, para visitar a su primo Joachim Ziessem, quien está enfermo de tuberculosis; irónicamente, el propio Hans debe internarse en el sanatorio, mientras Joachim sale del confinamiento, al cual sin embargo regresa tiempo después para morir; por su parte, Hans logra abandonar el sanatorio luego de varios años, pero sólo para enrolarse en una guerra donde lo espera una segura muerte. Cuando Pacheco alude a la novela de Koestler como "La montaña mágica", está sugiriendo la inutilidad de la labor de esos científicos, ganadores del Premio Nobel, para superar su egoísta naturaleza humana: confinados en una montaña en medio de los Alpes, todos están convencidos de que bastaría con su disciplina aislada para conjurar el inminente Apocalipsis, por lo cual no cooperan entre sí. La alusión a "Farenheit 451" es más directa, porque en el Chile de Pinochet también se quemaron libros, al igual que sucede en la novela de Ray Bradbury, aunque en esta última de modo generalizado. Ahora bien, como en ese inventario no se mencionan los nombres de Thomas Mann ni de Ray Bradbury, el lector debe poseer la competencia que le permita deducirlos a partir de la alusión a sus respectivas obras. No obstante (y espero que esto no se interprete como un elogio de la ignorancia), la pérdida que sufra quien carezca de esos datos será menor, por ejemplo, que la de una persona ignorante de quién es Ifigenia, si se atreve a leer el complejo poema dramático Ifigenia cruel (1924), de Alfonso Reyes.

En esta era digital, donde el acceso a Internet nos seduce con la idea de que se cumpla el sueño dibujado en "El Aleph" -es decir, que podamos poseer imágenes del universo entero mediante una sola ventana electrónica-, resulta arduo imaginar cómo fue la recepción inicial de algunos de estos textos. El penúltimo fragmento del inventario que comento se denomina "El tiempo recobrado", título de una de las siete novelas de la serie En busca del tiempo perdido. Pero en este caso sí aparece el nombre de Marcel Proust, porque se dice que Céleste Albaret, su fiel ama de llaves de 1914 a 1922, año de la muerte del escritor, acaba de publicar, a la provecta edad de 84 años (en realidad tenía 82), el libro Monsieur Proust. Pacheco no aclara que en el proceso de escritura ella había sido auxiliada por Geor- 
ges Belmont, cuyo nombre aparece en el subtítulo, en calidad de entrevistador. Hoy es fácil teclear el nombre para encontrar que, en efecto, Albaret publicó ese volumen en 1973, el cual apenas se tradujo al español en 2005; pero estoy seguro de que más de un lector creyó que Pacheco, al igual que hizo su maestro Borges con sus falsas reseñas, había inventado a Céleste.

Pacheco sintió atracción constante por este tipo de libros ancilares, según se percibe en un ejemplo literario muy posterior al período central aquí estudiado. Así, se enteró de que Epifania Úveda de Robledo, alias Fani, había escrito, con ayuda de un tercero, sobre su experiencia de décadas como criada de Borges. A partir de los recuerdos de Fani, Pacheco redactó un autoirónico y sabroso texto. En 1999, con motivo del centenario del nacimiento del autor argentino, él impartió una serie de conferencias en El Colegio Nacional, las cuales fueron compiladas en el pequeño volumen Borges; una invitación a su lectura, de casi nula circulación (pese a los inauditos cien mil ejemplares del tiraje, que no estuvo disponible para el público general, por razones ajenas al autor). Al final de esta obra, en una sección titulada "Jugar a Borges con Borges", él imita con fina ironía una exitosa estrategia de su maestro: elaborar reseñas sobre libros inexistentes. Por ello inventa que Fani, quien sirvió a Borges a partir de 1947 y hasta pocos meses antes de la muerte de éste en 1986, redactó la compilación Todo al fuego: notas de lectura, título alusivo a los quince mil libros enviados al escritor argentino por sus ingenuos admiradores, con la esperanza de ser leídos por el maestro; pero éste tan sólo los habría condenado a la hoguera. Antes de quemar todos los libros, Fani redactó lapidarias notas sobre ellos. En la dedicada a La sangre de Medusa, plaquette de apenas dos cuentos publicada en 1958 por Pacheco, quien supuestamente se la habría mandado a Borges, ella dictamina sin piedad: "Pobre de El Señor [Borges] con su cauda de imitadores lamentables. Estos cuentitos mexicanos me dieron la impresión de leer la prosa de Borges con el acento de Cantinflas" (1999, p. 116).

Añado otro detalle. Tal vez alguien juzgue que Pacheco fue un tanto cruel al describir la "literatura" (llamémosla así) de Corín Tellado, según analicé. Sin embargo, esta impresión se atenuaría si se recuerda que él emitió un juicio semejante sobre su primera incursión literaria. En la citada conferencia autobiográfica incluida en la compilación Los narradores ante el público, él confesó que sus primeros escarceos literarios nacieron 
mientras cursaba el año escolar en el extranjero; pasó el invierno de 1955 en una lúgubre ciudad de Estados Unidos (no especifica cuál), en un aislamiento absoluto (no entendía a nadie ni podía hacerse entender por nadie) que lo indujo a escribir "un novelón, Ella, que en el nombre lleva la fama" (1966, t. 1, p. 245), dice con irónica visión autocrítica. Como se ve en este ejemplo y en el previo, Pacheco también se burlaba y reía de sí mismo, una de las más virtuosas y sanas actitudes posibles para un ser humano, porque evita que nos tomemos demasiado en serio y creamos en nuestra irrefutable trascendencia. Desde una perspectiva retórica, la autoironía, cuyo estatuto teórico no ha sido plenamente elucidado, permite al sujeto enunciador desarmar al adversario, incluso antes de que éste emprenda el ataque.

Así como la ironía apareció desde el principio de su obra y se fue aguzando con el paso del tiempo, también sucedió lo mismo con otro rasgo de su escritura: la actitud ética, la cual se puede ilustrar con su texto del 9 de septiembre de 1973, titulado globalmente "Armas y letras". Según Ricardo Piglia (2001), Borges era un lector que veía siempre la misma página, pero con una perspicacia que nunca nadie había ejercido, porque, entre otros factores, se fijaba en detalles no perceptibles para los demás. De manera semejante, Pacheco se detiene en algunos resquicios de las publicaciones, los cuales por lo general pasan desapercibidos. El último fragmento de ese inventario, "The (ugly) beautiful people", empieza con una propuesta revolucionaria: "Muchas veces las cartas de los lectores son la parte más viva, interesante y significativa de las revistas". Para demostrar su arriesgada aseveración, él retoma un mero detalle de la revista Newsweek, en cuyo reciente número, de agosto, se había reproducido la carta de un lector de Nigeria, Ed Tomaslewicks, como reacción a una entrevista a la bellísima actriz, modelo y aristócrata Marisa Berenson, difundida pocas semanas antes. Según Berenson, desde los diecisiete años ya había visto medio mundo y conocido a toda la gente que lo merecía; por eso, a sus veintiséis años estaba aburrida de encontrarse con las mismas caras, en la Costa Azul, en París, en Roma, en los vestidores de los más prestigiosos diseñadores de moda. Como respuesta, Tomaslewicks asume una voz colectiva para hablar "En nombre de las multitudes afligidas por la sequía, hambrientas y agonizantes de Chad, Mali, Mauritania, Niger, Nigeria, Senegal y el Alto Volta”, y para invitar a Berenson a conocer la otra mitad 
del mundo, en donde, dice él, "estoy seguro de que ella verá las caras que nunca antes miró: los rostros del hambre, de la desesperación y de la muerte" (p. 16). Con esta cita finaliza el fragmento; es decir, además de su idea inicial sobre el valor de las misivas de los lectores, Pacheco no emite ningún juicio, sino que tan sólo funciona como mediador, porque aproxima a los lectores mexicanos a publicaciones extranjeras no asequibles, para empezar porque están en inglés, lengua que la mayoría de ellos desconoce. Pero como la literatura es esencialmente un polisémico fenómeno sintáctico, él no necesita añadir nada, pues al traducir unos pasajes de la carta y al explicar su contexto, genera un profundo sentido ético: si acaso Berenson leyó la indignada réplica del lector nigeriano, al menos habrá sentido vergüenza por haber desplegado tan infausta frivolidad.

El significado que asigno a la palabra ética proviene del teórico anglosajón Geoffrey Harpham (1995), quien a su vez se basa en las propuestas del filósofo franco-lituano Emmanuel Levinas. Al revisar el vínculo entre la ética y la literatura, Harpham propone ubicar esta problemática relación desde la perspectiva de la alteridad. Según él, ya que el arte verbal, en cuanto forma de representación, surge del mundo y del ámbito humano, entraña siempre una dimensión ética. De ahí la pertinencia de las propuestas teóricas de Levinas, para quien el centro de la ética reside en la absoluta e infinita obligación de considerar la figura que él llama "el otro". De todo ello concluye Harpham que la literatura podría encarnar lo que Levinas denomina la "circunstancia ética", o sea, el encuentro entre el yo y el otro. En este caso, la carta del nigeriano irrumpe en la revista Newsweek como la intromisión de una Otredad que no puede reducirse o asimilarse, pues se presenta como un elemento de choque que cuestiona la segura cosmovisión de los lectores, quienes no saben nada (o no quieren saber nada) de la hambruna africana; asimismo, al ser incluida en el Diorama de Excélsior, la carta traducida también lanza una bofetada a los lectores mexicanos, porque de inmediato la asociarán con las circunstancias de muchas poblaciones mexicanas muy desfavorecidas, donde también se perciben los rostros del hambre, la desesperación y la muerte (África no está tan lejos de nosotros).

He descrito apenas algunos fragmentos de los inventarios, sobre todo los de carácter ensayístico, si aceptamos las tradicionales divisiones genéricas, aun a sabiendas de que estos textos de Pacheco son un híbrido tanto de escritura reflexiva como 
narrativa, a veces con unos ápices de poesía, porque, por ejemplo, en uno de los inventarios de Excélsior aparecieron por vez primera poemas de Julián Hernández, uno de los heterónimos del escritor, así como otros textos poéticos suyos, originales o traducidos $^{6}$. Una muestra destacable de carácter narrativo se presenta en la entrega del 7 de abril de 1974, en cuyo segundo fragmento, titulado "La prueba de las promesas", se lee:

Hablaron del soldado español que estaba en Manila y de pronto se halló en la Plaza Mayor de México. Entonces alguien relató: Algo muy parecido ocurrió hacia 1972 en Buenos Aires. Había un tipo rarísimo pegando de gritos en Charcas y Esmeralda, muy asustado ante el tránsito, la gente, los edificios, los coches, el olor del aire.

$\mathrm{Al}$ principio creyeron que anunciaba un circo por como iba vestido, o bien que se trataba de un turista brasileño hablando un portugués de lo más raro, diciendo que era el Papa y antes había sido deán de Santiago, y estaba en Roma cuando un profesor de artes mágicas a quien conoció en Toledo le pidió ayuda para volver a España.

Él no accedió. Amenazó con hacerlo matar por hechicero, y entonces don Ilán dijo algo... y allí estaba el tipo en Buenos Aires, siete u ocho siglos después, que, por supuesto, para la eternidad son un instante.

Pero quién iba a creerle la historia si ya la conocían gracias al Infante Don Juan Manuel, Ruiz de Alarcón, Azorín, Borges. Lo refundieron en el manicomio porque, después de todo, el que se cree Papa castigado por su ingratitud hacia quien lo hizo Papa no será el primer español que se vuelve loco y se empeña en vivir lo que ha leído (p. 16).

${ }^{6}$ Tan dúctiles y variados son los inventarios, que su clasificación global resulta imposible. Sospecho que, en gran medida, ésta depende de la selección de textos suyos que cada lector haga, ante la imposibilidad de abarcarlos todos en un mismo y solo conjunto. Por ejemplo, al comentar algunos de los inventarios de la antología en tres volúmenes aquí mencionada, Asunción del Carmen Rangel López (2019) concluye que participan tanto de la crónica como de la crítica literaria. Por su parte, en su renuncia implícita a intentar clasificarlos como un género, Malva Flores (2017) describe los inventarios como un diálogo múltiple de Pacheco "con unos muertos que no lo están, porque seguimos leyéndolos, pero también un apasionado diálogo con la literatura, con el país y con el mundo; con los vivos y su circunstancia semanal" (p. 74). 
En apenas cuatro párrafos, Pacheco construye múltiples y ricas relaciones intertextuales. El título, "La prueba de las promesas", remite a una obra de Juan Ruiz de Alarcón, autor citado en el texto; la frase inicial, a una leyenda mexicana del siglo XVI, transmitida por Luis González Obregón ("Un aparecido") y retomada por Artemio de Valle Arizpe ("Por el aire vino, por la mar se fue"), según la cual en el México colonial sucedió un hecho inexplicable: un soldado que estaba en Manila, de pronto apareció en la Ciudad de México, sin que él ni nadie supiera cómo había acontecido todo, porque la leyenda no menciona al agente de tan mágico traslado (sólo se limita a reportar que la Santa Inquisición devolvió al aturdido filipino a Manila por barco). Este referente literario mexicano se entreteje con un texto español clásico: la historia de don Illán de Toledo, ofrecida primero por don Juan Manuel (Libro del conde Lucanor) y reelaborada después por un largo etcétera que incluye a Azorín ("Don Illán, el mágico") y a Borges ("El brujo postergado"), además, claro está, de Ruiz de Alarcón, cuya "Prueba de las promesas" recrea teatralmente la trama de don Juan Manuel.

En todos estos antecedentes, el castigo contra el deán de Santiago, cuya ingratitud hacia el nigromante que con su magia le ha dibujado un futuro promisorio no tiene límite, consiste tan sólo en su regreso a la situación inicial, o sea, al momento en que con fingida humildad solicita la enseñanza de los artilugios de la magia. Pacheco, en cambio, lanza al ingrato a Buenos Aires, una ciudad de otro continente, y lo ubica en un inconmensurable tiempo futuro: "siete u ocho siglos después, que, por supuesto, para la eternidad son un instante" (id.), como dice el texto. La idea de que cualquier lapso, computable en siglos o milenios, sería apenas un instante de la eternidad, proviene de Borges, quien pronuncia la última frase en el ensayo principal de su libro Historia de la eternidad. El cierre del texto, donde se menciona a otro enloquecido español que quiso hacer realidad sus lecturas, alude, claro está, al Quijote. En suma, en tan sólo cuatro breves párrafos, elabora Pacheco un múltiple entramado de relaciones intertextuales que muestran la riqueza de la literatura en lengua española, a ambos lados del Atlántico.

El texto que acabo de resumir es el segundo de una decena de fragmentos titulada "Diez ficciones", en obvio homenaje a Borges. En el primero de ellos, "El asesinato de Abraham Lincoln", Pacheco empezó a ejercer con libertad una novedosa práctica, que con el tiempo acabó siendo una de sus muy 
personales rúbricas: la invención de fábulas contrafactuales, es decir, aquellas donde solía imaginar sucesos que no concuerdan con el registro historiográfico o literario. En ese texto, fabula que el 14 de abril de 1865, el entonces presidente Lincoln estaba viendo una obra teatral identificada como "The murder of Abraham Lincoln", en la cual se interpretaría su muerte. Cuando Wilkes, el actor que encarnaba al asesino, dispara una bala que él creía de salva, mata involuntariamente a quien representaba al presidente Lincoln en escena, suceso que el Lincoln real aprovecha para desaparecer para siempre; mediante este engaño, él logra pasar a la historia como el líder de una Guerra de Secesión urdida no para defender al sistema productivo del norte industrial en contra del sur agrícola, sino para emancipar noblemente a los esclavos. A fines del siglo xix, oculto en su plantación de Virginia, el viejo Lincoln se reía contando esta exitosa historia, que le granjeó la posteridad, pues, concluye el texto, "sólo un gobernante asesinado puede preservar su gloria” (p. 16). Sin asumir un tono didáctico, en este inventario, donde se entrelazan de manera magistral la literatura y la historia, Pacheco imparte una lección histórica a sus receptores, quienes deben permanecer alerta para detectar los elementos lúdicos o irónicos de sus textos, rasgo imprescindible para descodificarlos de manera coherente, de acuerdo con su construcción misma. Así, cabe suponer que todos los lectores estarían al tanto del asesinato del presidente Lincoln en un teatro, además de que el texto se ubica bajo un claro artificio, al colocar una obra de arte dentro de otra ${ }^{7}$.

${ }^{7}$ En su inventario del 22 de abril de 1985, ya en la revista Proceso (pp. 50-51), Pacheco recordó que su columna "Simpatías y diferencias", de la Revista de la Universidad, había arrancado veinticinco años antes y que debía su título, homenaje al periodismo literario practicado por Alfonso Reyes en El Sol de Madrid, a Jaime García Terrés, quien generosamente había confiado la sección a un redactor de menos de veintiún años (Pacheco nació el 30 de junio de 1939). También señalaba que en ese 1985, algunos creían ver en la columna "Simpatías y diferencias" el germen de los inventarios. Sin duda esto es válido en cuanto a la vertiente ensayística de los inventarios, pero no en lo que se refiere a la poética ni a la narrativa. Tampoco primaba en los textos de esas colaboraciones el mejor tono irónico de sus escritos posteriores, ni el hábito contrafactual, que tantos dividendos le daría después. Menciono estos rasgos como un mero elemento descriptivo, porque, sin duda, a más de medio siglo de publicados, los textos de "Simpatías y diferencias" (disponibles ya por vía electrónica gracias a la generosa diligencia de la UNAM) siguen siendo igualmente disfrutables e ilustrativos. 
Aunque en sus ficciones contrafactuales Pacheco jugó con datos ampliamente conocidos, con el tiempo, este juego literario se fue aguzando, lo cual ilustro con un solo ejemplo. El 13 de enero de 1974, en el fragmento "Morir en Granada", habló de la muerte de García Lorca, con base en los datos proporcionados por el reciente libro de Ian Gibson. Después de numerosas menciones, en otros inventarios, a la obra de Lorca y a las circunstancias de su muerte, el 7 de junio de 1998, con motivo del centenario del nacimiento del poeta andaluz, escribió, ya en la revista Proceso, un texto completo ("García Lorca en México”) de carácter contrafactual. En él fabuló que García Lorca había muerto el 13 de marzo de 1966 en la Ciudad de México, a la que habría llegado treinta años antes para seguir desarrollando una prolífica carrera literaria. Nunca puede preverse cómo será la recepción de un texto, pues ésta también depende de las capacidades del lector. Por ello, no sería absurdo pensar que algún desprevenido lector hubiera ignorado que García Lorca fue asesinado en su país natal en agosto de 1936, en los albores de la Guerra Civil española. Esta probable confusión derivaría de las limitadas competencias de un receptor incapaz de seguir el delicado juego literario propuesto por el autor.

$$
\text { * * * * * * }
$$

Si acaso se me pidiera definir en una sola palabra qué son los inventarios, respondería sin dudar: una enciclopedia. Y de ningún modo creo ser hiperbólico, sino tan sólo justo. Eso sí, añadiría, tomando un término de Borges, que Pacheco es un escritor "enciclopédico y montonero", como el propio argentino se definió en 1928, en su libro El idioma de los argentinos. Según el diccionario de la Academia de la Lengua, al que a veces le asiste la razón, la palabra montonera se refiere a un "Grupo o pelotón de gente de a caballo que intervenía como fuerza irregular en las guerras civiles de algunos países sudamericanos" (s.v.). En el siglo XIx, la expresión adquirió un halo heroico, pues la montonera fue parte de la guerrilla que luchó por la Independencia de la región colonial de Sudamérica respecto de España. Cuando Borges hibrida los dos términos, enciclopédico y montonero, se refiere a alguien que llega a la cultura desde una posición sin privilegios; por ello, lo mismo se aplica el término a sí mismo que al poeta popular Evaristo Carriego, o bien a 
Richard Francis Burton, uno de los traductores de Las mily una noches. ¿Por qué montonero?: porque se trata de alguien que entra a saco en la cultura enciclopédica, pero con el más loable de los propósitos: asimilarla para transmitirla a los otros. De igual modo, un Pacheco enciclopédico y montonero cumple una extraordinaria función de mediador cultural, rasgo doblemente entrañable para sus lectores. Primero, porque les permite adquirir conocimientos inasequibles para ellos por vía directa. Segundo, porque incluso les posibilita simular cierta erudición, mediante el uso de los datos que él proporciona (la cultura también se adquiere por vía indirecta). En sus inventarios, Pacheco cumple un sentido ético entrañable, porque sus textos son un profundo encuentro del yo con los otros. Este aspecto es incluso perceptible en su estilo ensayístico, pues como afirma Juan Villoro al compararlo con Octavio Paz, uno de los más grandes ensayistas (y poetas) mexicanos del siglo xx:

Si el estilo ensayístico de Octavio Paz es el de quien deletrea el mundo desde su balcón con luminosa contundencia, sin pedir auxilio a las voces con las que dialoga, pero que rara vez llegan a sus páginas en forma de citas, José Emilio Pacheco es su contrafigura ensayística, el escribano que anuda los cabos sueltos de la tradición y se reconoce deudor de infinitos predecesores. En este sentido, "Inventario" representa la más dilatada muestra de cortesía en la literatura del idioma (2017, pp. 20-21).

Sospecho que a esta misma cortesía obedeció la búsqueda del anonimato de las columnas del inventario, llenas de nombres de autores y de títulos de libros, pero casi desnudas de la identidad de su autor. Y con ello me refiero no sólo a la ausencia de su nombre, sino también a la esporádica alusión a su propia obra y persona en muy pocos textos, en los cuales él más bien operó como alguien cuya individualidad se develaba cuando era acicateado por terceros (aunque siempre se disculpó con sus lectores por usurpar ese espacio para referirse a asuntos relacionados con él mismo). En el fondo, a Pacheco le interesaba superar la egoísta concepción del arte y de la originalidad que rige en nuestras culturas, la cual criticó desde 1965 en su mencionada conferencia:

La originalidad en arte, concepto nacido de la burguesía, cumplida su misión, está muriendo históricamente con ella. Quizá 
en adelante se eviten problemas haciendo que el arte sea, como en sus grandes épocas, anónimo y colectivo; concediendo ( admitir) a cada obra un solo año de vigencia, pasado el cual sería borrada y olvidada para siempre. Acaso de este modo terminarían las tristes, cíclicas luchas de generaciones, las enemistades, las ofensas, y al suprimir el egoísmo de sus creadores, el arte ganaría en número de artistas (1966, t. 1, p. 255).

En sentido estricto, él sólo triunfó en su empeño de hacer un arte colectivo, porque, de manera paradójica, el pretendido anonimato de sus inventarios se diluyó mediante su muy reconocible estilo de escritura: los lectores no requieren del nombre del autor para identificar sus inventarios.

Al principio de este trabajo cité, por medio de Ángel de Campo, al también cronista decimonónico Juvenal. De Campo prevé que la labor literaria de Juvenal alcanzará una valoración mayor con el transcurso de los años, porque "los sociólogos e historiadores; los novelistas reconstructores; los filósofos andan a caza de trajes, tipos, usanzas, locuciones, que retraten fielmente el pasado, y en ese sentido, por lo que a la clase media toca, Juvenal ha legado a los curiosos del porvenir, una cartera rica en esbozos, en códices y en caricaturas" (1991 [1903], p. 205). Pacheco también nos ha legado, a los curiosos del pasado, del presente y del porvenir, un universo que desborda en recreaciones literarias, pero no sólo de la sociedad y de la cultura mexicanas, sino también del amplio ámbito occidental, porque, sin duda, en su trabajo cotidiano él seguía al pie de la letra el consejo de Terencio: "Nada humano me es ajeno" 8 .

${ }^{8}$ La cita exacta en latín es Homo sum; humani nihil a me alienum puto, que se traduciría como "Hombre soy; nada humano me es ajeno". Aparece en la obra de Terencio Heautontimoroumenos (El atormentador de si mismo), donde es pronunciada por Cremes para justificar su intromisión en un asunto en apariencia ajeno. En la tradición cultural de Occidente, la cita, usada también por Karl Marx, se ha convertido en una máxima para designar cuál debería ser la conducta general de todos los seres humanos. Como se sabe, en la cultura mexicana, Alfonso Reyes acudió a esta sentencia, la cual transformó, en su famosa polémica de la década de 1930, en una frase retomada por Pacheco como título, el 11 de mayo de 1975, en un artículo del Diorama de la Cultura no perteneciente a la serie de los inventarios: "Nada puede sernos ajeno sino lo que ignoramos (Alfonso Reyes)". 


\section{REFERENCIAS}

Arreola, Juan José 1976. Inventario, Grijalbo, México.

Borges, Jorge Luis 1996 [1936]. "El arte de injuriar", Historia de la eternidad, en Obras completas, Emecé, Buenos Aires, t. 1, pp. 418-423.

Borges, Jorge Luis 1996 [1945]. "El Aleph", en Obras completas, Emecé, Buenos Aires, t. 1, pp. 617-627.

Campos, Marco Antonio 1977. "Mi diario, de Federico Gamboa”, Proceso, 7 de noviembre, pp. 60-62.

De Campo, Ángel (Micrós) 1991 [1903]. "Semana Alegre" (26 de julio), en La Semana Alegre. Ed. Miguel Ángel Castro, Universidad Nacional Autónoma de México, México, pp. 205-206.

Flores, Malva 2017. "Desde José Emilio Pacheco, otro inventario", Cuadernos Hispanoamericanos, 807, pp. 72-85.

García, Anne Cécile 2016. La réécriture dans l'oeuvre de José Emilio Pacheco. Une poétique du déjà-lu, Littératures, Université Paris-Est.

Gutiérrez Nájera, Manuel 1912. Hojas sueltas: artículos diversos. Prol. Carlos Díaz Dufóo, Imprenta Murguía, México.

Harpham, Geoffrey Galt 1995. "Ethics", en Critical terms for literary study. Eds. Frank Lentricchia \& Thomas McLaughlin, Chicago University Press, Chicago, pp. 387-405.

Hutcheon, Linda 1992. "Ironía, sátira y parodia", en De la ironía a lo grotesco (en algunos textos literarios hispanoamericanos). Trad. Pilar Hernández Cobos, UAM-Iztapalapa, México, pp. 173-193.

Musacchio, Humberto 2007. Historia del periodismo cultural en México, Conaculta, México.

Pacheco, José Emilio 1966. Texto sin título incluido en la colección Los narradores ante el público, Joaquín Mortiz, México, t. 1, pp. 241-273.

Pacheco, José Emilio 5 de agosto de 1973. "Inventario. «Las mariposas son libros. Boquitas selladas»", Diorama, Suplemento cultural de Excélsior, p. 16.

Pacheco, José Emilio 9 de septiembre de 1973. "Inventario. «Armas y letras»", Diorama, Suplemento cultural de Excélsior, p. 16.

Pacheco, José Emilio 15 de septiembre de 1973. "Inventario. «De Lautaro A Salvador Allende: un mínimo repaso»”, Diorama, Suplemento cultural de Excélsior, p. 16.

Pacheco, José Emilio 28 de octubre de 1973. "Inventario. «La montaña mágica». «El tiempo recobrado». «Farenheit 451»”, Diorama, Suplemento cultural de Excélsior, p. 16.

Pacheco, José Emilio 13 de enero de 1974. "Inventario. «Morir en Granada»", Diorama, Suplemento cultural de Excélsior, p. 16.

Pacheco, José Emilio 27 de enero de 1974. "Inventario. «Letras minúsculas»", Diorama, Suplemento cultural de Excélsior, p. 16.

Pacheco, José Emilio 7 de abril de 1974. "Inventario. «Diez ficciones»”, Diorama, Suplemento cultural de Excélsior, p. 16.

Pacheco, José Emilio 11 de mayo de 1975. "Nada puede sernos ajeno sino lo que ignoramos (Alfonso Reyes)", Diorama, Suplemento cultural de Excélsior, pp. 6-7. 
Pacheco, José Emilio 17 de agosto de 1975. "Inventario. «Pequeña guía de la cursilería»", Diorama, Suplemento cultural de Excélsior, p. 16.

Pacheco, José Emilio 14 de noviembre de 1977. "Inventario. «Recordación de Santa Clara»", Proceso, pp. 56-57.

Pacheco, José Emilio 22 de abril de 1985. "Inventario. «Veinticinco años después»", Proceso, pp. 50-51.

Pacheco, José Emilio 7 de junio de 1998. "Inventario. «García Lorca en México»", Proceso, pp. 60-61.

Pacheco, José Emilio 1999. Borges; una invitación a su lectura, Raya en el Agua, México.

Pacheco, José Emilio 2017. Inventario. Antología, Era-El Colegio NacionalUAS-UNAM, México, 3 ts.

Piglia, Ricardo 2001. "Borges como crítico", en Crítica y ficción, 2a . ed., Anagrama, Barcelona, pp. 149-169.

Rangel López Asunción del Carmen 2019. "Los inventarios de José Emilio Pacheco: una ajustada concepción poética", Cuadernos de Investigación Filológica, 45, pp. 109-127; doi: 10.18172/cif.3733.

Real Academia Española. Diccionario de la lengua española, 23 ${ }^{\mathrm{a}}$ ed. [versión 23.3 en línea], en https:/ / dle.rae.es [consultado el 15 de mayo de 2020].

Villoro, Juan 2017. La vida que se escribe. El periodismo cultural de José Emilio Pacheco, El Colegio Nacional, México. 
